\title{
Prototipe Sistem Pengontrolan dan Monitoring Pintu Berbasis Mikrokontroler
}

\author{
Prototype Door Control System and Monitoring Based Microcontroller
}

\author{
Jacquline M.S. Waworundeng*1, Ifan Kusumah' ${ }^{2}$, Rival Gimon ${ }^{3}$ \\ 1,2,3 Universitas Klabat Manado \\ E-mail: *1 jacquline.morlav@unklab.ac.id, ${ }^{2}$ gulasemut_20@yahoo.com, \\ ${ }^{3}$ rival.gimon@gmail.com
}

\begin{abstract}
Abstrak
Penelitian ini bertujuan untuk membuat prototipe sistem pengontrolan dan monitoring pintu yang bermanfaat untuk keamanan pintu pada sebuah bangunan. Sistem ini mengintegrasikan perangkat keras berbasis mikrokontroler yang dikontrol melalui perangkat lunak aplikasi Smart Building. Perangkat keras dibangun dengan Arduino, Digital Analog Converter (DAC), door strike, dan motor DC. Aplikasi Smart Building dibangun dengan Microsoft Visual Studio dan Arduino IDE. Operator menjalankan fungsi pengontrolan dan monitoring melalui aplikasi Smart Building pada komputer yang kemudian mengirimkan signal digital ke mikrokontroler yang diteruskan ke DAC. DAC mengkonversi signal digital menjadi signal analog yang dikirim ke device door stike dan motor DC yang terpasang di pintu. Sistem dapat melakukan fungsi kontrol seperti mengunci pintu, membuka kunci pintu, membuka pintu, dan menutup pintu. Fungsi monitoring terpantau melalui aplikasi yang dapat menunjukkan status pintu terkunci, tidak terkunci, terbuka atau tertutup. Hasil yang diperoleh menujukkan sistem pengontrolan dan monitoring pintu berfungsi sesuai dengan tujuan.
\end{abstract}

Kata Kunci — Smart Building, Monitoring, Mikrokontroler, Arduino, Digital Analog Converter.

Abstract

This study aims to create a Prototype System to control and monitoring the doors that useful for security doors in a building. This system-based on microcontroller integrated with software application Smart Building. Hardware built in with Arduino, Digital Analog Converter (DAC), door strike, and a DC motor. Smart Building applications built with Microsoft Visual Studio and the Arduino IDE. Operator control and monitoring function through Smart Building that installed on a computer which sends digital signals to a microcontroller that is forwarded to the DAC. DAC converts the digital signal into an analog signal that sent to the device door stike and DC motor mounted on the doors. The system can perform control functions such as door lock, door unlock, door open, and door close. Monitoring function monitored through applications that show the status of the doors weather locked, unlocked, open or closed. The results showed the door control system and monitoring function in accordance with the purpose.

Keywords - Smart building, Monitoring, Microcontroller, Arduino, Digital Analog Converter. 


\section{PENDAHULUAN}

Seiring dengan perkembangan teknologi, pengunaan peralatan yang dapat berfungsi secara otomatis, telah menjadi kebutuhan yang dapat membuat pekerjaan menjadi lebih mudah dan praktis. Penggunaan mikrokontroler banyak menghasilkan sistem yang otomatis misalnya pada sistem keamanan yang diaplikasikan pada pembuatan bangunan pintar. Peneliti membuat prototipe sistem pengontrolan dan monitoring pintu pada bangunan sebagai bagian dari sistem keamanan. Sistem ini menggunakan aplikasi yang dijalankan dari komputer, yang dapat mengontrol dan melakukan monitoring terhadap status dan kondisi pintu pada bangunan. Rumusan masalah dalam penelitian ini yaitu bagaimana membuat prototipe sistem pengontrolan dan monitoring pintu pada bangunan menggunakan mikrokontroler yang dapat dikontrol lewat aplikasi komputer. Tujuan penelitian adalah membuat sistem pengontrolan dan monitoring pintu dengan memanfaatkan perangkat lunak maupun perangkat keras. Penelitian ini bermanfaat untuk dapat mempermudah pengontrolan dan monitoring pintu untuk meningkatkan sistem keamanan pada bangunan.

\subsection{Bangunan dan Rumah Pintar}

Berbagai penelitian seperti Smart Home System, menghasilkan sebuah sistem berbantuan komputer yang memberikan segala kenyamanan, keselamatan, keamanan dan penghematan energi, yang berlangsung secara otomatis dan terprogram melalui komputer, pada gedung atau rumah [1].

Penelitian yang berjudul Perancangan Smart Home Berbasis Programmable Logic Controller bertujuan membuat kendali otomatis untuk mengendalikan alat-alat elektronik, peralatan listrik dan lampu serta pengontrolan gerbang [2]. Khusus untuk fungsi pengontrolan gerbang didapati bahwa, sensor infrared dan limit switch digunakan untuk membuka dan menutup gerbang, dengan remote infrared dan push button untuk pengontrolannya. Pengontrolan dalam sistem tersebut tidak dilakukan melalui aplikasi komputer.

Penelitian terkait lainnya berjudul Perancangan Software Aplikasi Pervasive Smart Home. Sistem rumah cerdas merupakan konsep smart dan pervasive yang terdiri dari perangkat kontrol, monitoring dan otomatisasi beberapa perangkat atau peralatan rumah yang saling berinteraksi dan dapat diakses melalui sebuah komputer. Monitoring dilakukan menggunakan beberapa sensor dan kamera yang dihubungkan pada komputer. Pada sistem kontrol, komputer dapat memberikan perintah langsung untuk mengaktifkan equipment. Perancangan sistem ini menggunakan mikrokontroler AT89S51 sebagai pengatur dan pengendali seluruh perangkat pada sistem smart home yang dihubungkan dengan komputer sebagai pusat kontrol melalui interface RS232. Komunikasi antara komputer dengan mikrokontroler menggunakan data serial dan menggunakan bahasa pemrograman Visual Basic 6.0 [3]. Penelitian ini menunjukkan bahwa pengontrolan peralatan dilakukan melalui aplikasi komputer.

\subsection{Mikrokontroler}

Mikrokontroler pada dasarnya adalah sebuah komputer chip tunggal (single chip). Single chip berarti seluruh sistem komputer berada dalam sebuah silicon yang dienkapsulasi dalam sebuah board circuit yang saling terhubung dan dapat menyimpan dan menjalankan program. Mikrokontroler mempunyai komponen utama yaitu memori (RAM/ROM), Central Processing Unit (CPU), jalur Input/Output (I/O), timer, dan interrupt controller[4].

Arduino board merupakan mikrokontroler yang dapat diprogram untuk memproses input maupun output yang keluar dan masuk dalam chip. Arduino dikenal sebagai platform komputasi fisik yang berinteraksi lingkungan software maupun hardware. Arduino dapat dihubungkan ke komputer untuk mengambil atau mengirim data.

Untuk memprogram Arduino, programmer menggunakan Arduino Integrated Development Environment (IDE). Arduino IDE adalah software yang dapat diprogram dalam bahasa $\mathrm{C}$ yang dimengerti oleh Arduino. Arduino IDE memungkinkan programmer menulis 
program komputer, berupa serangkaian instruksi, dan melakukan upload ke Arduino. Arduino mengambil instruksi tersebut dan berinteraksi dengan lingkungan sistem [5].

Penelitian ini menggunakan Arduino sebagai komponen utama yang akan menghubungkan program aplikasi dengan pengontrolan dan monitoring pintu.

\subsection{Enkripsi dan Dekripsi}

Enkripsi adalah proses mengamankan suatu informasi dengan membuat informasi tersebut tidak dapat dibaca tanpa bantuan pengetahuan khusus. Enkripsi merupakan proses untuk mengubah plainteks menjadi chiperteks. Plainteks adalah data atau pesan asli yang ingin dikirim, sedangkan Chiperteks adalah data hasil enkripsi. Definisi lain tentang Enkripsi adalah proses mengacak data sehingga tidak dapat dibaca oleh pihak lain. Dekripsi dalam dunia keamanan komputer merupakan proses untuk mengubah chiperteks menjadi plainteks [6]. Enkripsi dan dekripsi dalam penelitian prototipe sistem pengontrolan pintu berbasis mikrokontroler, digunakan dalam aplikasi Smart Building sebagai bagian dari otentikasi operator yang menjalankan aplikasi dari komputer.

\subsection{Rekayasa Perangkat Lunak}

Rekayasa Perangkat Lunak merupakan pembentukan dan penggunaan prinsip rekayasa untuk memperoleh perangkat lunak secara ekonomis yang handal dan bekerja secara efisien. Metode ini memperbolehkan ilmu pengetahuan menjadi suatu rancangan perangkat lunak dalam memperoleh kinerja yang sesuai dengan persyaratan spesifikasi yang ditentukan dalam penelitian [7]. Rekayasa Perangkat Lunak juga merupakan cara-cara pengembangan perangkat lunak termasuk pembuatan, pemeliharaan, manajemen organisasi pengembangan perangkat lunak, dan sebagainya [8].

Peneliti menggunakan metode Rekayasa Perangkat Lunak karena dapat meningkatkan fungsionalitas dan efisiensi aplikasi dan juga kemudahan dan efisiensi dari pengembangan perangkat lunak.

\section{METODE PENELITIAN}

Metode penelitian mencakup desain penelitian, kerangka konseptual sistem, perancangan perangkat keras, dan perancangan perangkat lunak aplikasi smart building.

\subsection{Desain Penelitian}

Peneliti menggunakan model Prototyping karena merupakan model yang terus berkembang, dapat cepat menyesuaikan dengan kebutuhan pengguna melalui feedback dari pengguna. Gambar 1 menunjukkan tahapan pada model prototyping yang terdiri atas communication, quick plan, modeling quick design, construction of prototype, deployment delivery and feedback [7]. 


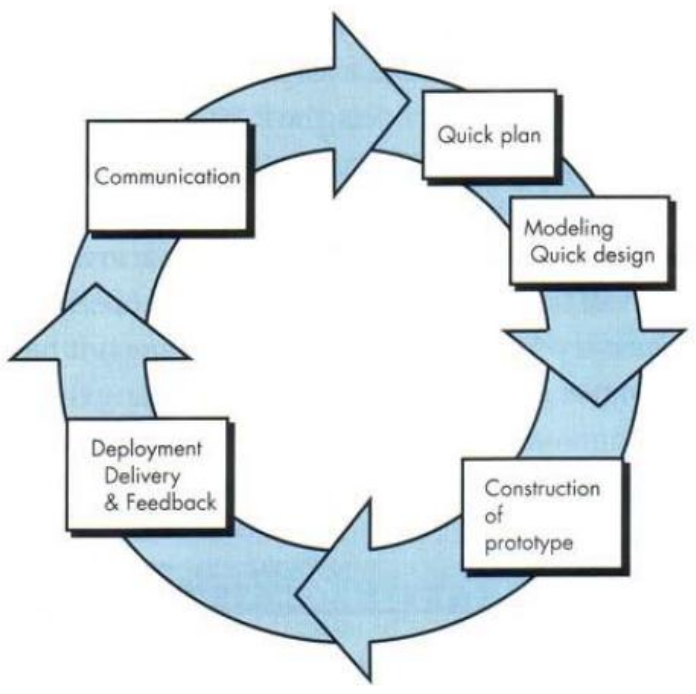

Gambar 1. Model Prototyping

Model prototyping, menjadi acuan bagi peneliti untuk menyusun desain penelitian seperti pada Gambar 2.

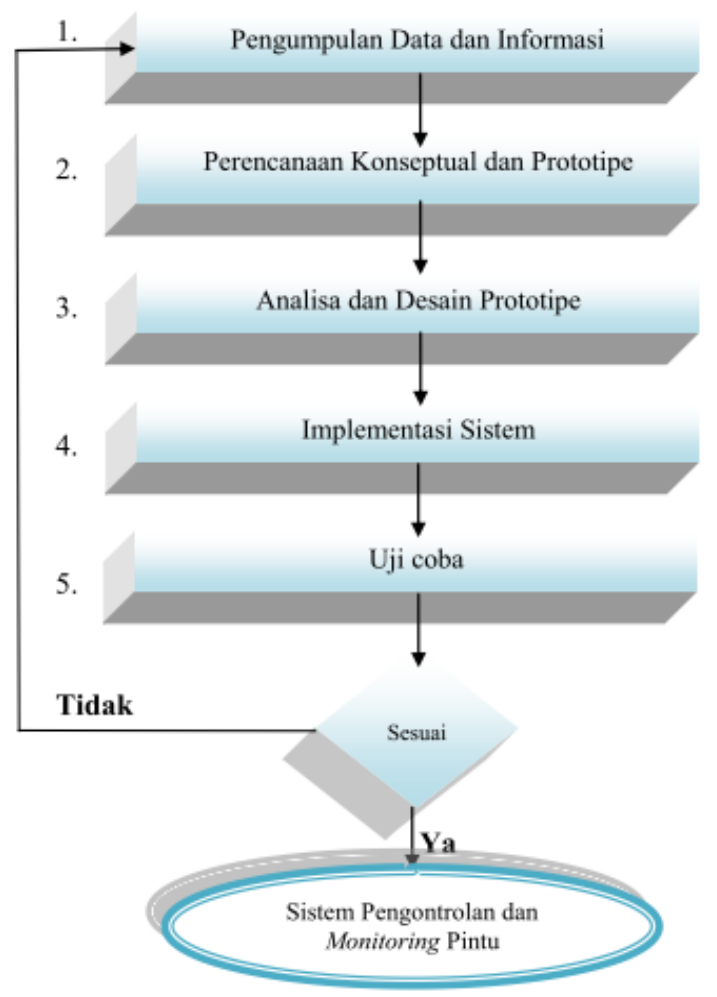

Gambar 2. Desain penelitian sistem pengontrolan dan monitoring pintu

Tahapan dalam desain penelitian sistem pengontrolan dan monitoring pintu dijelaskan sebagai berikut.

1. Pengumpulan data dan informasi: peneliti mencari kebutuhan yang diperlukan dengan melakukan pengumpulan data dan informasi, dilakukan dengan cara mengumpulkan informasi melalui literatur, jurnal, buku-buku, dan internet untuk mengetahui bagaimana cara perancangan sistem pengontrolan dan monitoring pintu. 
2. Perencanaan Konseptual dan Prototipe: peneliti melakukan perencanaan konseptual dari sistem seperti modul dan alat-alat yang dibutuhkan dalam pembuatan sistem, merancang skema rangkaian elektronika maupun miniatur bangunan yang akan digunakan.

3. Analisa dan Desain Prototipe: peneliti menganalisa dan kemudian merancang prototipe sistem berdasarkan hasil identifikasi dan komponen-komponen yang dibutuhkan untuk dijadikan referensi dalam sistem yang dibuat.

4. Implementasi Sistem: peneliti telah membuat rancangan interface dari sistem ini dan melakukan pengkodean menggunakan tools yang mendukung untuk pengembangan sistem ini. Semua tools yang telah didapatkan telah digunakan dalam pembuatan sistem hingga sistem tersebut bisa dijalankan.

5. Uji coba: Pengujian dilakukan untuk memastikan sistem telah berjalan dengan baik dan fungsi atau fitur-fitur yang telah dirancang dan dikembangkan berfungsi dengan baik. Jika belum sesuai maka pengguna memberikan feedback kepada peneliti untuk melakukan iterasi pada tahap-tahap sebelumnya.

Setelah melewati proses pada konseptual penelitian maka Sistem Pengontrolan dan Monitoring Pintu sudah selesai dibuat dimana fungsi-fungsi dari aplikasi telah berfungsi sesuai dengan tujuan.

\subsection{Kerangka Konseptual System}

Kerangka konseptual sistem menjelaskan tentang cara kerja sistem pengontrolan dan monitoring pintu. Gambar 3 menjelaskan cara kerja sistem pengontrolan dan monitoring pintu. Pertama, operator memberi perintah melalui aplikasi Smart Building yang terinstal pada komputer. Perintah tersebut dapat mengirimkan fungsi ke device (pintu) seperti mengunci pintu, membuka kunci pintu, membuka pintu, dan menutup pintu. Kemudian, komputer mengirim signal digital ke mikrokontroler dan diubah menjadi signal analog oleh Digital Analog Converter (DAC). Selanjutnya signal analog tersebut dikirim ke device door strike. Door strike adalah alat pengunci pintu elektronik yang menggunakan magnet dan mengunci pintu apabila diberi tegangan dan membuka pintu apabila tidak diberi tegangan. Ketika fungsi tersebut berhasil dijalankan, maka operator akan menerima feedback dari komputer, yaitu kondisi pintu terkunci atau tidak terkunci dan pintu terbuka atau tertutup.

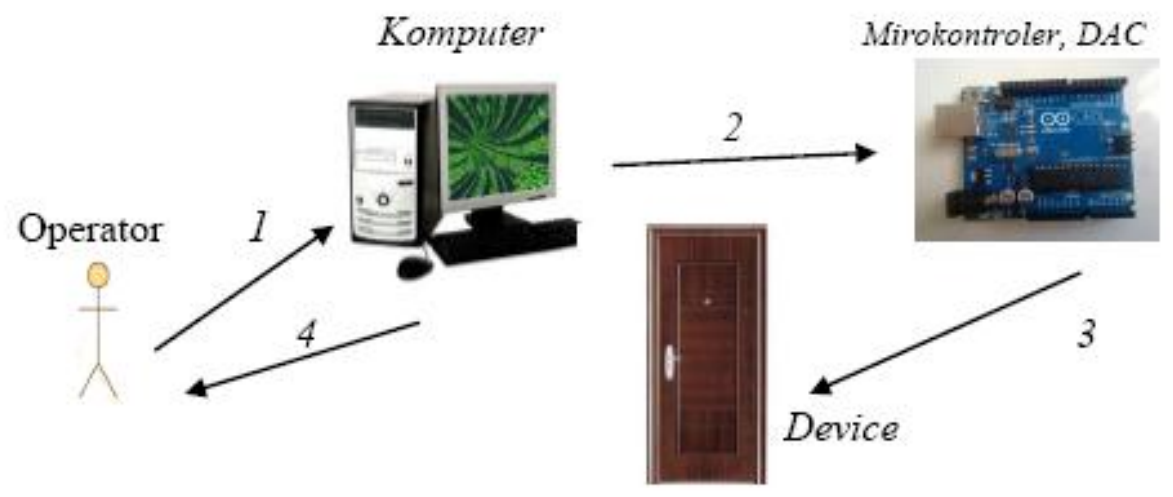

Gambar 3. Kerangka konseptual sistem pengontrolan dan monitoring pintu

\subsubsection{Perancangan perangkat keras}

Gambar 4 memperlihatkan prototipe alat yang menggunakan mikrokontroler, Integrated Circuit (IC) dan DAC. Ketika operator memberikan perintah dari aplikasi Smart Building, maka komputer mengirimkan signal digital yang telah diproses oleh aplikasi ke mikrokontroler melalui 
koneksi serial port. Mikrokontroler mengirimkan signal digital tersebut ke DAC, kemudian DAC akan mengubah signal digital menjadi signal analog. Signal analog tersebut akan menyalakan device pada pintu yaitu, kunci listrik (door strike) dan motor DC.

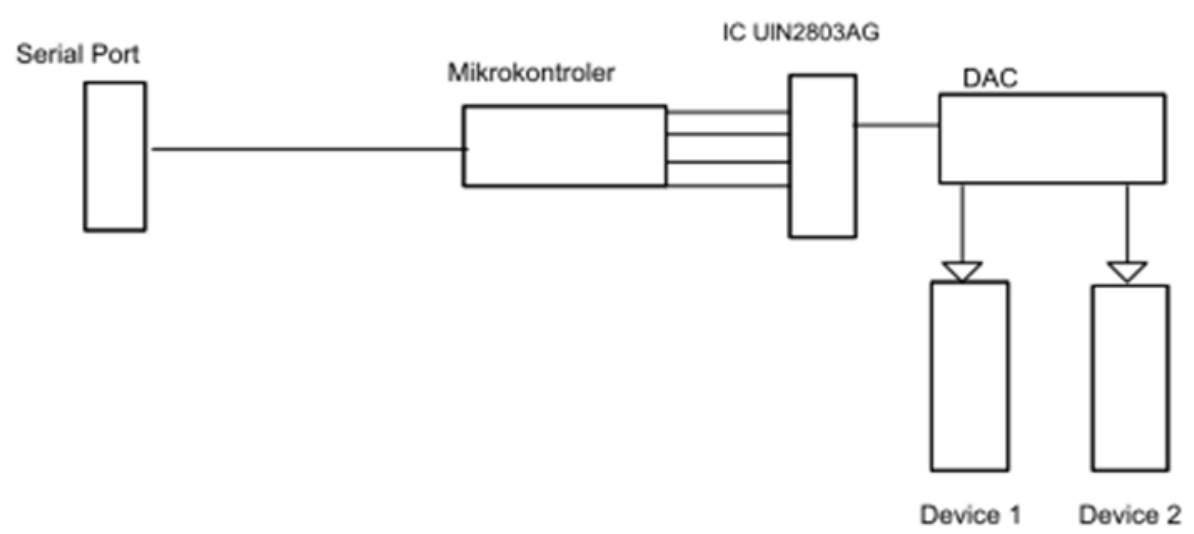

Gambar 4. Perancangan alat

Perancangan perangkat keras terkait dengan penggunaan DAC. DAC adalah alat yang dapat mengubah signal digital menjadi signal analog yang akan memberikan arus atau muatan listrik pada alat elektronik yang digunakan. Gambar 5 memperlihatkan desain DAC. Ketika operator memberikan perintah pada aplikasi untuk mengontrol pintu, komputer akan mengirimkan signal bernilai 1 pada serial port. Signal yang bernilai 1 memiliki tegangan 3,5 - 5 volt. Serial port dapat mengirimkan 8 signal ke IC ULN 2803AG. Tegangan 3,5 - 5 volt yang berasal dari serial port diubah oleh IC ULN 2803 menjadi 12 volt negatif dan dikirimkan pada relay coil negatif. Tegangan 12 volt positif yang berasal dari adaptor dikirimkan pada relay coil positif. Relay coil dihubungkan dengan device pada pintu.

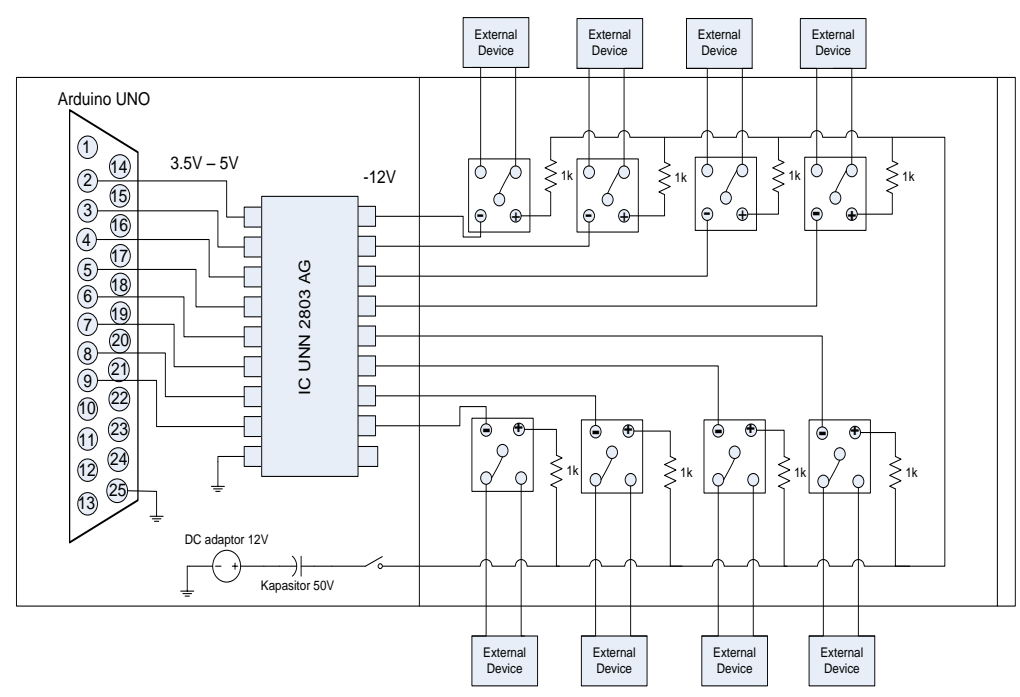

Gambar 5. Digital Analog Converter

\subsubsection{Perancangan Perangkat Lunak Aplikasi Smart Building}

Perancangan perangkat lunak dijelaskan dengan use case diagram. Gambar 6 menunjukkan use case diagram aplikasi smart building. Use case terdiri dari dua actor yaitu operator 1 dan operator 2. Terdapat 6 use case terdiri yaitu: start application, setting, lock door, unlock door, open door dan close door. Use case ini merupakan fungsi utama aplikasi smart 
Citec Journal, Vol. 3, No. 2, Februari 2016 - April 2016

ISSN: 2354-5771

building. Operator dapat mengaktifkan aplikasi, mengganti password, melakukan pengontrolan dan monitoring setiap pintu.

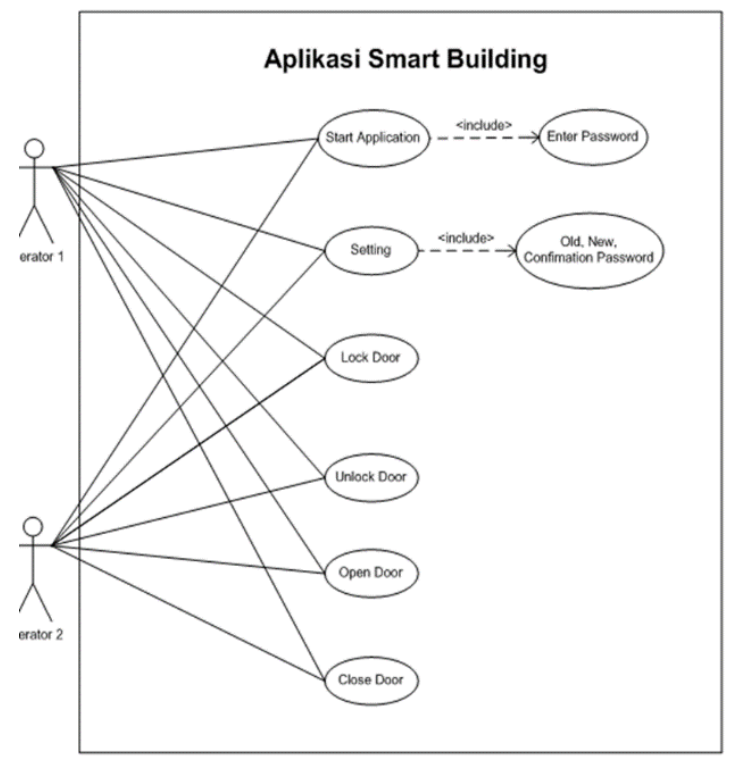

Gambar 6. Use case diagram aplikasi smart building

\begin{tabular}{|c|}
\hline Login \\
\hline $\begin{array}{l}\text {-inputPassword : string } \\
\text {-path : string } \\
\text {-passEncrypt : string } \\
\text {-msg : string } \\
\text {-password : string } \\
\text {-decryptedString : string }\end{array}$ \\
\hline $\begin{array}{l}\text { +Login } 0 \\
\text { + InitializeComponent0 } \\
\text { +decryptString } 0 \text { : string } \\
\text {-getDecryptedPassword } 0 \text { : string } \\
\text {-pressEnter0 : void } \\
\text { +gotoMainApplication } 0 \text { : void } \\
\text { +invalidPassword } 0 \text { : void } \\
\text { +buttonLoginCancel0 : void } \\
\text { +buttonLoginOk0 : void }\end{array}$ \\
\hline
\end{tabular}

\begin{tabular}{|c|}
\hline MainApplication \\
\hline $\begin{array}{l}\text { +door1_statusLU : int } \\
\text { +door1_status OC: int } \\
\text { +door2_statusLU : int } \\
\text { +door2_status OC: int } \\
\text { + SerialPort0; }\end{array}$ \\
\hline 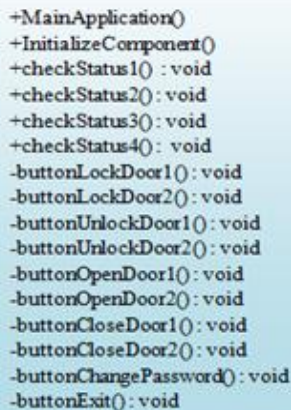 \\
\hline
\end{tabular}

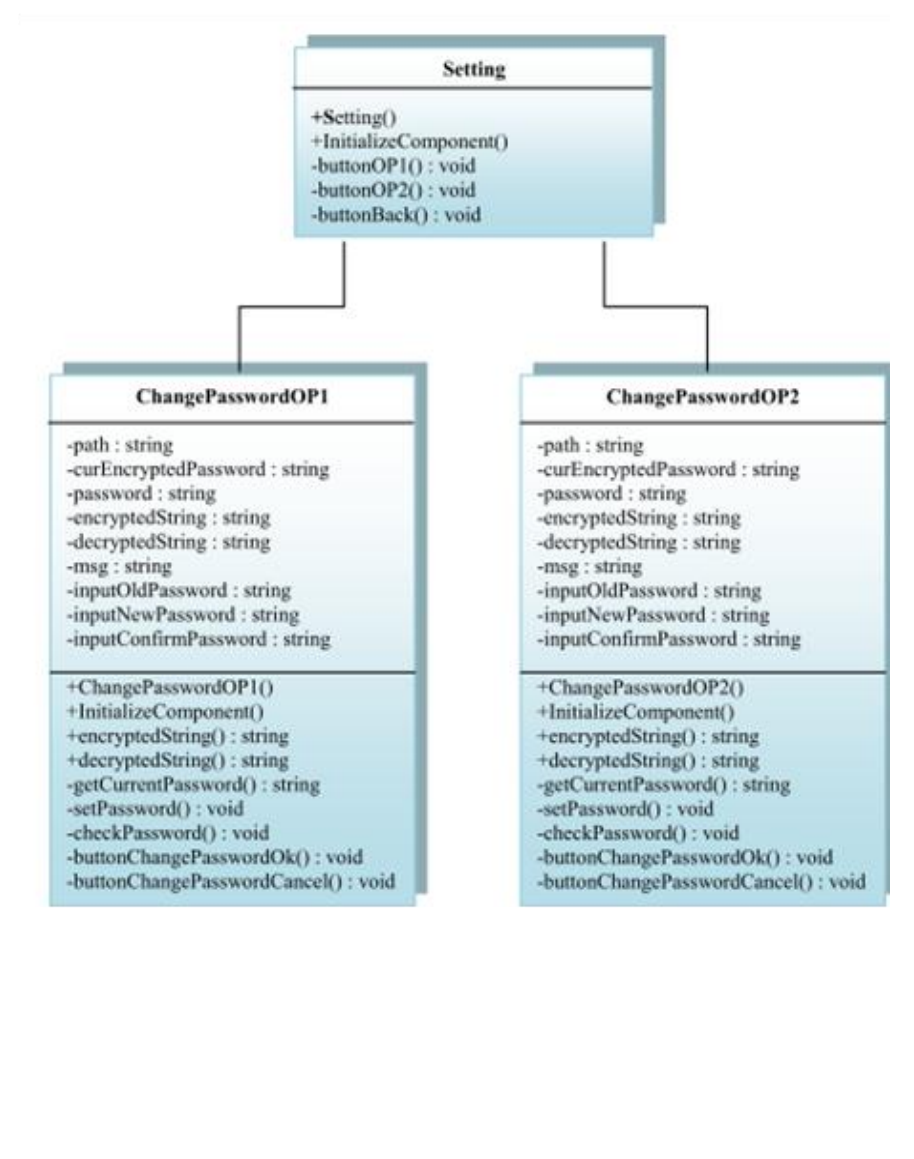

Gambar 7. Class diagram Login, Setting dan Main Application 
Arsitektur aplikasi digambarkan melalui perancangan menggunakan Class Diagram yang terdiri atas fungsi dan data yang akan digunakan pada aplikasi Smart Building, seperti pada Gambar 7. Class Login pada aplikasi yang berisi data dan fungsi-fungsi untuk melakukan verifikasi password. ClassSetting pada aplikasi berisi data dan fungsi untuk melakukan pengaturan password. ClassMainApplication berupa data status pintu, berdasarkan perintah operator lock door/unlock door dan open door/closedoor pintu.

\section{HASIL DAN PEMBAHASAN}

\subsection{Implementasi Perangkat Keras untuk Sistem Pengontrolan dan Monitoring Pintu}

Implementasi perangkat keras yang digunakan untuk membuat DAC berupa komponen elektronika yaitu satu Printed Circuit Board (PCB), satu Adaptor 12 Volt, satu Kapasitor 50 Volt, satu IC ULN2803AG, satu Diode, delapan Relay 12 Volt, delapan Resistor 1 Kilo Ohm, delapan buah LED 5 Volt, dan kabel.

Gambar 8 merupakan implementasi DAC yang digunakan untuk mengubah signal digital dari komputer ke mikrokontroler melalui serial port menjadi signal analog untuk melakukan pengontrolan terhadap device yang ada pada pintu. Terdapat 8 output yang dapat digunakan untuk melakukan pengontrolan terhadap device.

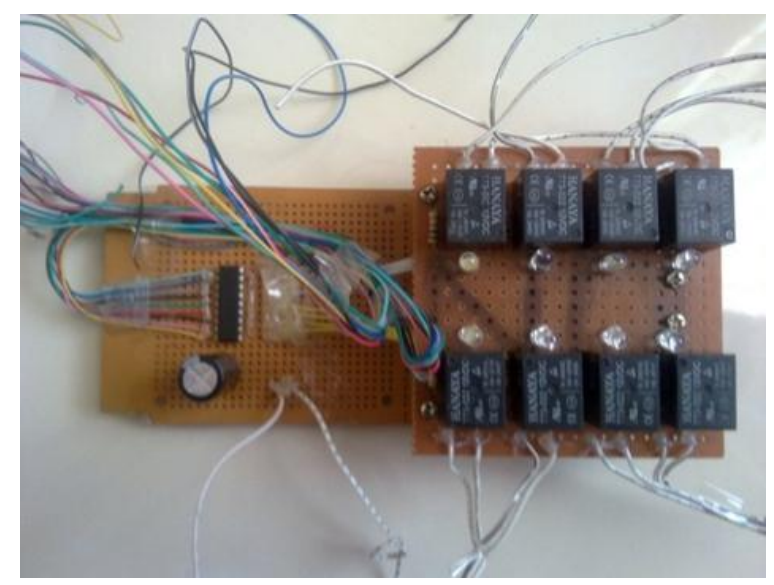

Gambar 8. Digital Analog Converter

Gambar 9 merupakan miniatur bangunan dengan dua pintu. Terdapat dua ruangan yang memiliki satu pintu pada masing-masing ruangan. Pada setiap pintu terpasang door strike dan motor DC yang akan berfungsi sesuai dengan perintah dari aplikasi.

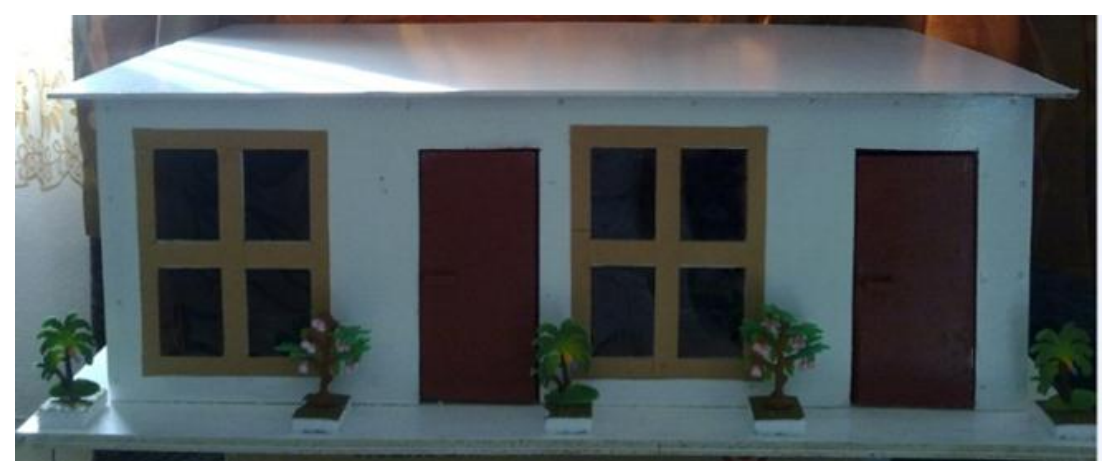

Gambar 9. Miniatur ruangan dengan dua pintu 


\subsection{Implementasi aplikasi Smart Building}

Aplikasi Smart Building yang dijalankan melalui komputer, dibangun dengan menggunakan Microsoft Visual Studio 2010 yang diintegrasikan dengan Arduino IDE. Aplikasi pada sistem pengontrolan dan monitoring pintu pada bangunan, dapat melakukan pengontrolan lock door, unlock door, open door, close door dan memonitor kondisi pintu.

Aplikasi ini dikembangkan menggunakan .NET Framework 3.0 dan menggunakan Digital Analog Converter yang terpasang 8 buah relay yang berfungsi sebagai switch. Dibutuhkan 6 buah switch. Setiap switch open door 1, close door 1, open door 2, close door 2, lock dan unlock door 1 , lock dan unlock door 2.

Gambar 10 merupakan tampilan antarmuka Login dan Main Application. Terdapat button untuk lock, unlock, open, close pintu dan button change password dan exit. Adapun label untuk memberikan status dari setiap pintu, combo box untuk mengambil port yang tersedia, dan group box.

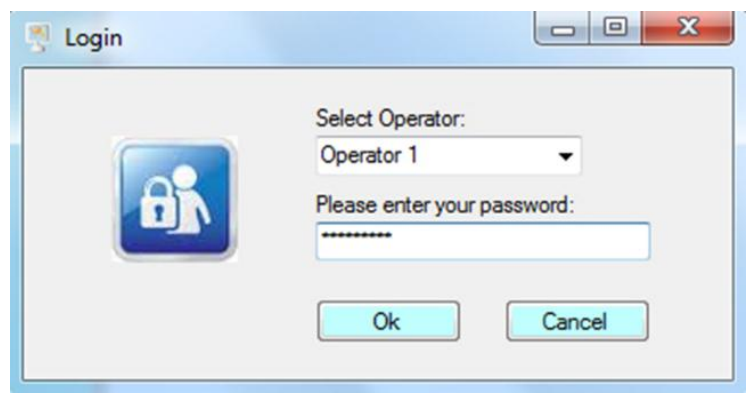

Gambar 11. Tampilan Antarmuka Login Operator

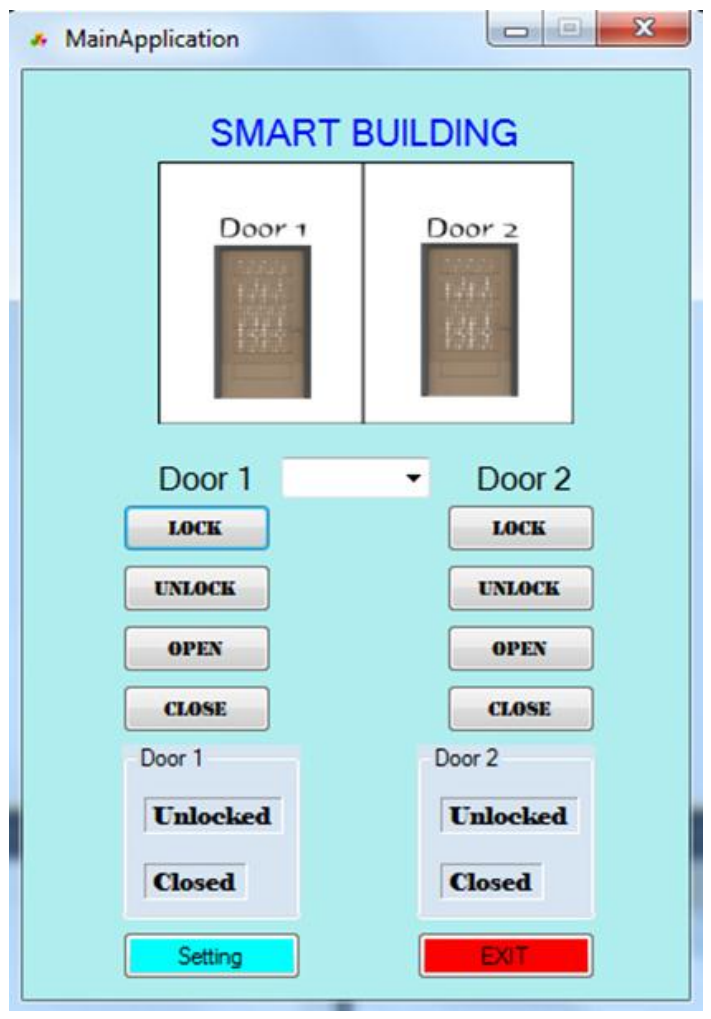

Gambar 10. Tampilan Antarmuka Aplikasi Smart Building

Tabel 1 menunjukkan hasil pengujian fungsi-fungsi dalam aplikasi Smart Building yang terintegrasi dengan prototipe alat pengontrolan dan monitoring pintu. 
Tabel 1. Hasil Pengujian Sistem

\begin{tabular}{|c|c|c|c|c|}
\hline No & Kasus Uji & Kondisi & Hasil yang diharapkan & $\begin{array}{l}\text { Hasil yang } \\
\text { didapatkan }\end{array}$ \\
\hline \multirow[t]{3}{*}{1.} & \multirow[t]{3}{*}{ Lock door 1} & Door Lock \& Closed & $\begin{array}{l}\text { Pintu masih dalam kondisi terkunci dan } \\
\text { tetap tertutup }\end{array}$ & Sesuai \\
\hline & & Door Unlock \& Open & $\begin{array}{l}\text { Pintu tidak bisa terkunci karena masih } \\
\text { dalam status terbuka }\end{array}$ & Sesuai \\
\hline & & Door Unlock \& Closed & Pintu terkunci dan status masih tertutup & Sesuai \\
\hline \multirow[t]{3}{*}{2} & \multirow[t]{3}{*}{$\begin{array}{c}\text { Unlock Door } \\
1\end{array}$} & Door Lock \& Closed & $\begin{array}{c}\text { Kunci pintu terbuka dan status pintu } \\
\text { masih tertutup }\end{array}$ & Sesuai \\
\hline & & Door Unlock \& Open & $\begin{array}{l}\text { Pintu masih dalam kondisi kunci } \\
\text { terbuka dan status masih terbuka. }\end{array}$ & Sesuai \\
\hline & & Door Unlock \& Closed & $\begin{array}{l}\text { Pintu masih dalam kondisi kunci } \\
\text { terbuka dan status masih tertutup. }\end{array}$ & Sesuai \\
\hline \multirow[t]{3}{*}{3} & \multirow[t]{3}{*}{ Lock Door 2} & Door Lock \& Closed & $\begin{array}{l}\text { Pintu masih dalam kondisi terkunci } \\
\text { dan tetap tertutup }\end{array}$ & Sesuai \\
\hline & & Door Unlock \& Open & $\begin{array}{l}\text { Pintu tidak bisa terkunci karana masih } \\
\text { dalam status terbuka }\end{array}$ & Sesuai \\
\hline & & Door Unlock \& Closed & $\begin{array}{c}\text { Pintu terkunci dan status masih } \\
\text { tertutup }\end{array}$ & Sesuai \\
\hline \multirow[t]{3}{*}{4} & \multirow[t]{3}{*}{$\begin{array}{l}\text { Unlock Door } \\
2\end{array}$} & Door Lock \& Closed & $\begin{array}{l}\text { Kunci pintu terbuka dan status pintu } \\
\text { masih tertutup }\end{array}$ & Sesuai \\
\hline & & Door Unlock \& Open & $\begin{array}{l}\text { Pintu masih dalam kondisi kunci } \\
\text { terbuka dan status masih terbuka }\end{array}$ & Sesuai \\
\hline & & Door Unlock \& Closed & $\begin{array}{l}\text { Pintu masih dalam kondisi kunci } \\
\text { terbuka dan status masih tertutup }\end{array}$ & Sesuai \\
\hline \multirow[t]{3}{*}{5} & \multirow[t]{3}{*}{ Open Door 1} & Door Lock \& Closed & $\begin{array}{l}\text { Pintu tidak dapat dibuka karena dalam } \\
\text { kondisi terkunci }\end{array}$ & Sesuai \\
\hline & & Door Unlock \& Open & $\begin{array}{c}\text { Pintu masih dalam kondisi tidak } \\
\text { terkunci dan masih terbuka }\end{array}$ & Sesuai \\
\hline & & Door Unlock \& Closed & Pintu dapat dibuka & Sesuai \\
\hline \multirow[t]{3}{*}{6} & \multirow[t]{3}{*}{ Close Door 1} & Door Lock \& Closed & $\begin{array}{l}\text { Pintu masih dalam kondisi terkunci } \\
\text { dan tertutup }\end{array}$ & Sesuai \\
\hline & & Door Unlock \& Open & Pintu dapat ditutup & Sesuai \\
\hline & & Door Unlock \& Closed & $\begin{array}{c}\text { Pintu masih dalam kondisi tidak } \\
\text { terkunci dan tertutup }\end{array}$ & Sesuai \\
\hline \multirow[t]{3}{*}{7} & \multirow[t]{3}{*}{ Open Door 2} & Door Lock \& Closed & $\begin{array}{c}\text { Pintu tidak dapat dibuka karena dalam } \\
\text { kondisi terkunci }\end{array}$ & Sesuai \\
\hline & & Door Unlock \& Open & $\begin{array}{c}\text { Pintu masih dalam kondisi tidak } \\
\text { terkunci dan masih terbuka }\end{array}$ & Sesuai \\
\hline & & Door Unlock \& Closed & Pintu dapat dibuka & Sesuai \\
\hline \multirow[t]{3}{*}{8} & \multirow[t]{3}{*}{ Close Door 2} & Door Lock \& Closed & $\begin{array}{l}\text { Pintu masih dalam kondisi terkunci } \\
\text { dan tertutup }\end{array}$ & Sesuai \\
\hline & & Door Unlock \& Open & Pintu dapat ditutup & Sesuai \\
\hline & & Door Unlock \& Closed & $\begin{array}{l}\text { Pintu masih dalam kondisi tidak } \\
\text { terkunci dan tertutup }\end{array}$ & Sesuai \\
\hline
\end{tabular}

\section{KESIMPULAN}

Berdasarkan hasil yang didapatkan maka ditarik kesimpulan sebagai berikut:

1. Prototipe sistem pengontrolan dan monitoring pintu dibuat dengan menggunakan perangkat keras dan perangkat lunak. Komponen utama untuk perangkat keras berupa komponen elektronika, digital analog converter (DAC), dan Arduino. Sedangkan perangkat lunak berupa aplikasi smart building dibuat dengan menggunakan Microsoft Visual Studio dan Arduino IDE.

2. Pengontrolan dan monitoring kondisi pintu pada bangunan dilakukan melalui antarmuka aplikasi komputer. Dengan menggunakan aplikasi smart building, maka operator dapat mengetahui status pintu dan mengatur kondisi pintu tertutup terkunci, tertutup tidak terkunci, atau terbuka. 
3. Hasil yang diperoleh menunjukkan bahwa prototipe sistem pengontrolan dan monitoring pintu ini dapat berfungsi sesuai dengan desain sistem.

\section{SARAN}

Berdasarkan penelitian yang dilakukan,masih ada beberapa kekurangan yang terdapat dalam aplikasi sistem tersebut yang perlu dibenahi. Untuk itu diberikan saran kepada pemakai dan pengembang aplikasi berikutnya

1. Pengembangan penelitian dapat dilakukan dengan mengintegrasikan sistem pengontrolan dan monitoring pintu dengan kamera CCTV yang dapat merekam situasi dalam ruangan untuk keamanan yang lebih maksimal.

2. Sistem pengontrolan dan monitoring pintu pada bangunan dapat dikembangkan menjadi sistem yang multi fungsi dengan menambahkan fitur-fitur lainnya seperti pengontrolan lampu maupun peralatan elektronik lainnya.

\section{DAFTAR PUSTAKA}

[1] Meyer, G., 2005, Smart Home Hacks. O’Reilly Media, Inc, United State of America.

[2] Triawati, E. \& Aritonang, F., 2010, Perancangan Smart Home Berbasis Programmable Logic Controller, Seminar Nasional dan Sistem Intelijen KOMMIT, Jakarta, 24 November 2010.

[3] Yurmama, T. F., Azman, N., 2009, Perancangan Software Aplikasi Pervasive Smart Home, Seminar Nasional Aplikasi Teknologi Informasi (SNATI), Yogyakarta, 20 Juni 2009.

[4] Iovine, J., 2004, PIC Robotics - A Beginner's Guide to Robotics Projects Using the PIC Micro, McGraw Hill, New York.

[5] McRoberts, M., 2010, Beginning Arduino, Springer, New York.

[6] Pfleeger, C. P., Pfleeger, S. L., 2006, Security in Computing fourth Edition, Prentice Hall, New Jearsy.

[7] Pressman, R. S., 2009, Software Engineering: A Practitioner's Approach, 7th International edition, McGraw-Hill, New York.

[8] Simarmata, J., 2009, Rekayasa Perangkat Lunak, Penerbit Andi, Yogyakarta. 